\title{
Nekrolog: Vagn Greve 1938-2014
}

\section{Av Thomas Elholm och Per Ole Träskman}

Det är alltid svårt att skriva en nekrolog - och då särskilt en minnesruna över en duktig kollega och en nära vän. Detta gäller särskilt nu för oss med anledning av att Vagn Greve är död. Vagn Greve, som var född den 9 mars 1938, avled i sitt hem den 18 juli 2014 efter att han under ett par års tid varit cancersjuk.

Vagn Greve föddes i Nørre Lyndelse på Fyn, där hans far var föreståndare för en ungdomsskola. Nørre Lyndelse är en liten landsby, som kanske är mest känd för att också Carl Nielsen var född där. Ungdomsskolans ideologi grundades på N.F.S. Grundtvigs och Christen Kolds idéer. I en intervju har Vagn Greve själv deklarerat att: "Jeg er opvokset $i$ en landsby på

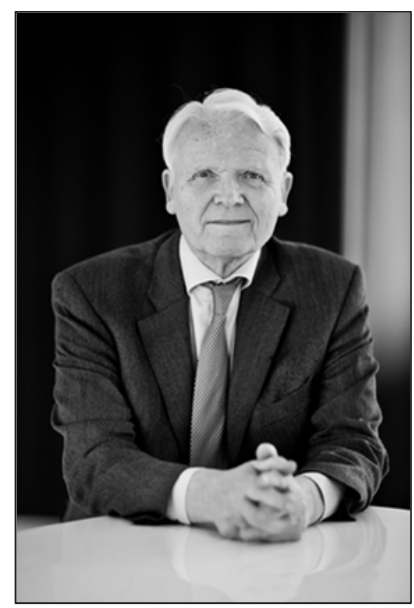
en ungdomsskole baseret på Grundtvig og Christen Kolds ideer. Grundtvigs princip om »mennesket forst« var en dyd i min familie. Det var den kultur, jeg blev dannet af."

Sedan kan man undra över och diskutera vad uttrycket "mennesket først" egentligen betyder och hur Vagn Greve tog det till sig i sitt professionella liv som jurist och kriminalvetenskaplig forskare. En tolkning är att det betyder att människorna ska ha fokus på livet här och nu på denna jord och med en stark betoning av att det är universellt att vara människa: "At vaere menneske er guddommeligt uanset, hvilken religion eller tro eller ikke-tro man tilslutter sig". Under alla omständigheter lägger det en god grund för en humanistisk inställning till brottskontroll och straff - och det hade Vagn Greve.

Vagn Greve studerade juridik vid Københavns universitet där han blev juris kandidat 1965 och juris licentiat 1972. Det var också där han var anställd det mesta av sitt professionella liv, först som amanuens, senare som lektor och ännu senare (1992-2008) som professor i straffrätt. Avstickare från Köpenhamns universitet gjorde han till Handelshøjskolen i København (numera CBS), först som professor i revision särskilt med fokus på ekonomisk kriminalitet (1987-92) och 
senare som professor i kriminalret vid Center for Kreditret og Kapitalmarkedsret (2009-2012). Under flera år verkade han också som dekanus för den juridiska fakulteten vid Köpenhamns universitet.

Som kriminalvetenskaplig forskare var Vagn Greve både mångsidig och koncentrerad. Mångsidigheten kommer till uttryck i att han forskade och publicerade skrifter inom flera av straffrättens områden. Fokuseringen syns åter i att han lämnade straffrätten bara då det var viktigt för hans straffrättsliga forskning samt i att han hade vissa klara ledstjärnor med avseende på den grundläggande synen på vad som utmärker en god straffrätt. Han önskade alltid placera den straffrättsliga regleringen i nutiden, men med ett starkt betonande av dess sociala, kulturella och historiska kontext. Han insmickrade sig inte för politiskt korrekt populism utan betonade alltid den vetenskapliga forskningens betydelse för vad som är riktigt, han försvarade individuella friheter, särskilt upplysning och yttringsfrihet (ibland kanske till och med överdrivet) och han var allt i allt en humanistiskt intellektuell forskare.

Det finns ingen grund att ifrågasätta Vagn Greves flit och stora ambitioner. Han publicerade ett mycket stort antal vetenskapliga verk, både stora och små. Till de stora hör böckerna, lagkommentarerna, läroböckerna och flera monografier också om de delar av straffrätten som på grund av sin speciella karaktär blir mer sällan föremål för seriös forskning. Till dem hör trafikstraffrätten, den ekonomiska brottsligheten, den fiskala straffrätten, internationell straffrätt inklusive EU-straffrätten, den danska straffrätten i de gamla kolonierna etc. Vagn Greves författarskap omfattar också kriminologi och ett ansenligt antal arbeten med en viss rättshistorisk prägel. Flera av artiklarna berör intrikata ämnen som blasfemi, bigami, incest, tidelag och ärekränkning.

Kärnstraffrätten behandlas framför allt i Kommenteret straffelov, både Almindelig del och Speciel del som utkommit i flera upplagor med Vagn Greve som medförfattare, samt läroböckerna, inte minst läroböckerna Det strafferetlige ansvar och Straffene. Det är två inspirerande och pedagogiskt välupplagda läroböcker för akademiska studier.

Vagn Greve var en aktiv professor också utanför universitetet. Han var medlem av Den Særlige Klageret (en speciell dansk institution som avgör frågor om resning och ändringssökande till Högsta domstolen) och Straffelovrådet (ett permanet lagförberedande organ). Han var också ordförande för den danska Kriminalistföreningen och utsågs till en av dess hedersmedlemmar. Han var därtill under ett antal år huvudredaktör för tidskriften Juristen.

Principen om "mennesket først" kom bl.a. till uttryck i Vagn Greves samhälls engagemang. Via sin ställning på universitetet och sin aktivitet inom Dansk Kri- 
minalistforening tog han flitigt och ihållande initiativ till fackliga arrangemang med syfte både att upplysa och debattera. Bara sällan avhöll han sig för att säga sin mening och detta gällde också med avseende på massmedia som han hade daglig kontakt med under många år. Vad han uttalade kunde ibland framstå som provocerande, som då han argumenterade för att incest mellan syskon borde avkriminaliseras. Men helt i linje med principen om "mennesket først" kunde hans uttalanden också komma grupper av människor till undsättning som upplevde sig vara klämda av normerna. För denna insats fick han vid ett antal tillfällen både officiellt och inofficiellt ett stort erkännande. Han fick t.ex. AIDS-fondens forskningspris år 1994.

Vagn Greves uttalanden var alltid baserade på hans grundläggande principer, hans människosyn och på en grundlig och skarpsinnig facklig insikt. Också hans läroböcker präglas av denna blandning - kanske särskilt böckerna Straffene og Det Strafferetlige Ansvar. I dem upplyser Vagn Greve å ena sidan noggrant och utförligt läsaren om vad som gäller, medan han samtidigt låter sin grundläggande hållning till rättssystemet och reglerna skina igenom texten. Vagn Greve hade en encyklopedisk känsla för att se och registrera alla detaljer som kunde kasta ljus över ett ämne, och i hans pedagogiska verksamhet förenades dessa element på ett sätt som var berikande - detta gav i verkligheten associationer till upplysningstidens ideal om upplysning och humanitet.

I denna minnesanteckning finns det en särskild grund att lyfta fram hans insatser för det nordiska samarbetet. Han var en mycket långvarig huvudredaktör för denna tidskrift, Nordisk Tidskrift for Kriminalvidenskab, och också en flitig artikelförfattare i den. Han har utarbetat ett systematiskt register till tidskriften för åren 1983-2012 i tillägg till det register som han var med om att utarbeta för tiden före detta. Han deltog aktivt i Nordiska Samarbetsrådet för Kriminologis arbete och han var en av initiativtagarna till den Nordiska workshopen i Straffrätt som arrangerats årligen sedan år 1996. Vagn Greve fick hederstiteln, juris doktor honoris causa både vid Uppsala universitet och vid Helsingfors universitet.

Det är som nämnt alltid svårt att skriva en nekrolog - och då särskilt en minnesruna över en duktig kollega och en nära vän. För oss var Vagn just detta - en ganska ovanlig blandning av markant facklighet och nära vänskap. 